\title{
共通顆題 水田農業の今日的課題と展開方向
}

\section{一第37回関西農業経済学会大会報告一}

座長治部田幸範

長期にわたる構造的米生産過剩下にあって本年度か らは「水田農業確立対策」なる標語によって転作が強 化されつつあるし, 他方では, 近時, 米価引き下げ, 農業保護削減, 米穀輸入等々の問題が国の内外から次 第に大きく喧伝されている. 折しも, 本年度生産者米 価が31年ぶりに，しかむ $5.95 \%$ と大幅に引き下げられ たことは記憶に新しい. 強い価格支持と食糧管理とに よって，長い間稲作仙傾斜して安住してきたわが国の 水田農業は, まさに, 簃しい正念場を迎えるに至って いるのである. 乙の秋に当り, 水田農業の基本的問題 を整理検討し，その展開方向を見定めることは極めて 緊要かつ意義深いことである. 上記共通課題を設定し たわけはそこにある.

そこで，われわれは主として政策・制度の側面及び 地代・地価の側面加ら, 水田農業の今日的課題を明ら 玑し, その上で, 水田農業の展開方向を, わが国で も代表的な農業地域, 積雪寒冷単作地帯及び西南暖地 2 毛作地帯について探究するとととした. そのような 視点加ら, 次の 4 課題を設定し, それぞれ 4 氏に報告 をお願いした。

報告 I「水田農業をめぐる政策・制度の今日的課題」 （増井幸夫氏）では，稲作農業の構造改善を阻害して いるものは農地法規制及び価格支持であり，てれらの 見なおしてそが水田農業の産業的自立のために求めら れているとした. 報告 II 水田農業の展開と地代・地 価問題」(宮崎 猛氏)では, 米価低落は農地賃貸借に 関して, 次第に地片的短期契約から経営農地の長期契 約へと移行させるし, 他方, 地価上昇は今後も続くで あろうから, 農地売買に比較した農地賃貸借の有利性 が強まるとした. 報告III「北陸地方における水田経営 の展開方向」(棚田光雄氏)では, 北陸稲作地帯に特長 的に成立している借地大型稲作経営の成立発展の諸条 件について事例的に検討した. 報告 $\mathrm{V} 「 山$ 山陽地方にお ける水田経営の展開方向」(甲田斉氏)では, 山陽 2 毛 作地帯では集約的土地利用を基本とする規模桩大及び
複合化が農業経営の今後の方向とされるが,そのうち, 若干の代表的経営方式の展開条件を事例的に検討し た.

そして報告 I に対しては山本修氏（神戸大）に，報 告にに対しては中島征夫氏（農業研究センター）に, 報告亚に対しては亀谷是氏（京都大）に；報告IVに対 しては波多野忠雄氏（中国農試）にコメントを打願い した. いずれも課題設定, 分析方法等に関して適切な コメントが加えられ，報告内容や論点の整理の上に立 って多岐にわたる意見開陳が行なわれた.

コメンテーターからのコメントとフロアからの質疑 応答, 見解交換は極めて活発に行なわれたが，それら の主要点は次の通りであった．報告 I に対しては，最 重要の論点, 米価水準の引き下げは兼業零細農の場合 には必ずしあ農地流動化に結びつかないのではないか との議論, 報告Пに対しては，米価と小作料及び土地 改良投資と地価上昇の相互関係並びに，「地域持分経 営」の概念規定等についての質疑，意見交換，報告III に対しては, 借地型個別経営をとりあげた理由, 経営 大型化のための条件整備, 低コストの検討等いろいろ な指摘, 報告IVに対しては, 稲麦 2 毛作地帯における 経営方式多様化の諸要因の検討,「地域農業調整組織」 の考え方についての質疑が行なわれた.

最後に, 論点を経営形態 (個別, 集団) 及び米のコ ス卜低隇可能性（技術, 生産規模) の 2 点にしぼっ て, 水田農業を総合的に討論することとしたが, 時間 の制約もあって十分な展開ができなかった.しかし， 全体としては活発な討論を通じて理論的に水田農業の 今日的課題に迫り, 代表的な農業地域について地域農 業の展開方向を現実的に見出そうとしたわれわれの意 図は一応達せられたと考える. 今回のシンポジゥムの 成果がこの分野の研究に今後大きく貢献することが期 待されるのである.

(筆者・新潟大学農学部) 